\title{
PENGARUH MANAJEMEN TALENTA TERHADAP KINERJA PEGAWAI UBP KARAWANG
}

Citra Savitri ${ }^{1)}$,Enjang Suherman ${ }^{2)}$,

Jl. HR. Ronggowaluyo Telukjambe Timur/Citra.savitri@ubpkarawang.ac.id

Jl. HR. Ronggowaluyo Telukjambe Timur/ Enjangsuherman@ubpkarawang.ac.id

Manajemen Fakultas Bisnis dan Ilmu Sosial, Universitas Buana Perjuangan Karawang

\begin{abstract}
Abstrak
Manajemen talenta akan berdampak kepada keberhasilan suatu lembaga. Kurangnya kemampuan dalam membaca peluang, mengembangkan keterampilan, strategi perusahaan akan berdampak negatif terhadap keberlangsungan suatu Lembaga. UBP Karawang merupakan perguruan tinggi yang tujuannya adalah mencetak, menciptakan sumber daya manusia yang diharapkan mampu bersaing dan mengembangkan diri bagi perusahaan tempat ia bekerja nantinya. Penelitian ini bertujuan untuk mengetahui bagaimana manajemen talenta dalam mempengaruhi kinerja karyawan di UBP Karawang.

Metode yang digunkan dalam penelitian ini adalah kuantitatif deskriptif. Jumlah sampel yang dapatkan adalah sebanyak 63 yang diampil dengan menggunakan simple random sampling. Data diperoleh langsung dari responden dengan menggunakan kuisioner. Sedangkan analisis yang digunakan adalah regresi linier sederhana.

Hasil penelitian menunjukan bahwa terdapat pengaruh signifikan manajemen talenta terhadap kinerja pegawai sebesar $37,8 \%$. Adapun regresi sederhana nya adalah $\hat{y}=8,997+0,592 x$ berarti bahwa satu kenaikan manajemen talenta meningkatkan 0,592 kinerja pegawai.
\end{abstract}

\section{Keyword : Manajemen Talenta, Kinerja Karyawan}

\section{PENDAHULUAN}

Sukses dalam Talent Management sangat penting karena akan berdampak pada kesuksesan sebuah organisasi (Mellahi, 2009). Keberhasilan organisasi ditentukan oleh sumber daya manusia yang berbakat (Boudreau, 2005) dimana sumberdaya manusia diatur dalam bidang pengelolaan manajemen sumber daya manusia yang secara khusus mempelajari hubungan dan peran manusia dalam pengorganisasian perusahaan (Wright, 2011) dengan kata lain, Talent Management bukan hanya sekedar proses tunggal atau bagaimana program pengembangan berjalan, melainkan mencakup serangkaian proses (Farndale, 2010). Hal tersebut didukung dengan perubahan jaman yang terus mengalami peningkatan dimana era revolusi industry 4.0 menuntut sumberdaya manusia lebih cepat tanggap dalam membaca peluang dan SMD yang memiliki talenta akan mudah untuk menghadapi persaingan secara mudah.

Keberhasilan sebuah perusahaan salah satunya adalah bagaimana SDM mampu untuk mengelola dengan baik (Bratton, 2012) dan talent managemen merupakan sebuah konsep mulai dari bagaimana merencanakan, mendapatkan, mengembangkan dan mempertahankan bakat (Isanawikrama, 2017). Berdasarkan pendapat diatas maka dapat disimpulkan bahwa talent 
management memiliki peran penting bagi organisasi karena dengan kemampuan dalam mengembangkan talenta, merencanakan dan membangun talenta akan berdampak pada hasil positif bagi perkembangan perusahaan.

Tantangan terbesar manajemen saat ini adalah memenangkan perang talenta ( Talent War) dimana situasi ketika perusahaan slaing berlomba mengalahkan pesaing mereka untuk memperoleh talenta terbaik yang ada dalam pasar tenaga kerja (Iwan Sukoco \& Ashar R. F., 2016). Dengan demikian, perusahaan harus melakukan yang terbaik untuk meningkatkan kesediaan karyawannya untuk bertahan di perusahaan atau yang disebut employee retention (Ramlall, 2003).

Masalah yang sering terjadi dalam sebuah organisasi antara lain adalah kurang mampunya dalam membaca peluang dalam mengembangkan perusahaan dan ketidakmampuan dalam membuat strategi yang berdampak bagi pengembangan usaha organisasi. Manajemen talenta memegang peran penting dalam peningkatan kinerja organisasi yang berdampak pada loyalitas karyawan kepada perusahaan.

Perguruan Tinggi merupakan salah satu lembaga yang tujuannya adalah mencetak, menciptakan sumber daya manusia yang diharapkan mampu bersaing dan mengembangkan diri bagi perusahaan tempat ia bekerja nantinya. Oleh sebab itu Universitas Buana Perjuangan (UBP) Karawang ingin terwujudnya visi dan misi perguruan tinggi maka lembaga harus memastikan bahwa perencanaan, pengelolaan dan pengembangan pegawai UBP Karawang yang dilakukan dapat terukur, terarah, terstruktur dan efektif sehingga dapat menghasilkan talenta terbaiknya dan memberikan kontribusi besar bagi perusahaan.

Menjadi perguruan tinggi yang kompetitif dan berwawasan internasional tentunya menjadi pekerjaan bagi seluruh stakeholder yang ada pada perusahaan tersebut, penerapan manajemen talenta yang dilakukan oleh UBP Karawang mampu memberikan keuntungan dan nilai bagi keberlangsungan perusahaan. Berikut adala penerapan yang dilakukan UBP Karaang dalam menggunakana tenaga ahli dan mengelola talenta yang dimiliki.

Teori Manajemen Talenta

1. Manajemen Talenta disebut sebagai HCM (Human Capital Management), HRIS ( $H R$ Management system) (Darmin, 2011)
Implementasi pada UBP Karawang

1. Pada UBP Karawang manajemen talenta bedara pada HRIS ( HR Management system)

131. Jurnal Buana Ilmu 
2. Karyawan yang diidentifikasi memiliki potensi menjadi pemimpin masa depan perusahaan adalah orng yang memiliki talenta dan sebagai objek dalam penerapan manajemen talenta (Darmin, 2011)

3. Terdapat sekumpulan SDM perusahaan yang memiliki keterampilan berkualifikasi (talent pool) (Darmin, 2011)

4. Manajemen talenta secara luas adalah manajemen stratgei untuk mengelola aliran talenta dalam suatu organisasi dengan tujuan memastikan tersedianya pasokan talenta untuk menyelaraskan orang yang tepat dan pada waktu yang tepat (Darmin, 2011)
2. UBP Karawang melalukan sasaran manajemen talenta secara global dan seluruh pegaawai yang ada di UBP Karawang adalah objek dari manajemen talenta.

3. Belum tersedianya talent pool

4. UBP Karawang dalam mengelola aliran dalam perusahaan memastikan bahsa pasokan yang dibutuhkan sesuai dengan job description nya dan sejalan dengan Visi dan misi organisasi.

\section{Rumusan Masalah}

Pembahasan menjadi terarah maka dilakukan rumusah dalam artikel yaitu bagaimana pengaruh manajemen talenta terhadap kinerja pegawai UBP Karawang?

\section{Tujuan Penelitian}

Penelitian ini bertujuan untuk menganalisis bagaimana pengaruh manajemen talenta terhadap kinerja pegawai di UBP Karawang.

\section{Tinjauan Pustaka}

\section{a. Definisi Talent Management}

(Lockwood, 2005) menyatakan bahwa manajemen talenta merupakan implemetasi dari sebuah strategi dan sistem yang terintegrasi dalam meningkatkan produktivitas dalam bekerja dengan mengembangkan, mempertahankan dan menggunakan SDM sesuai dengan skill yang dibutuhkan saat ini maupun masa yang akan datang. 
(Lewis, 2006) mendefiniskan manajemen talenta sebagai sebuah proses secara keseluruhan dalam merekrut, menempatkan merencanakan dan mengembangkan kemampuan seseorang untuk mendapatkan kesuksesan. Sedangkan (Yamall, 2011) mengatakan bahwa manajemen talenta mencakup dalam pemilihan dan pengembangan karyawan yang dianggap berbakat dalam perusahaan yang dihasilkan perusahaan yang dapat dikembangkan bakatnya untuk menjadi sebuah investasi dalam perusahaan.

Maka dapat disimpulkan bahwa manajemen talenta merupakan sebuah upaya dalam mencari, mengembangkan, merencanakan dan mempertahankan bakat yang dimiliki seseorang dalam sebuah organisasi yang diperlukan untuk mengembangkan bisnis perusahaan dan aset bagi perusahaan yang harus terus dipelihara.

\section{b. Proses Talent Management}

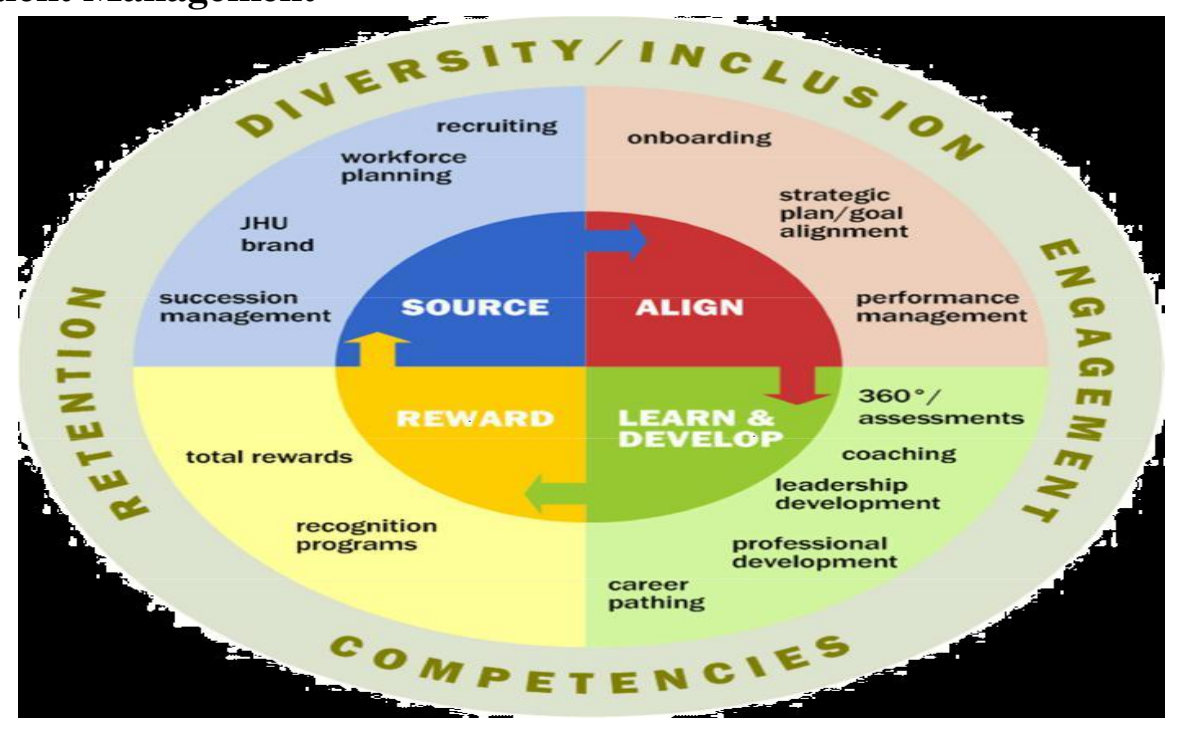

Gambar 1. Proses Talent Manajement

Sumber: The Office of Talent Management and Organization Development

Berdasarkan gambar diatas maka dapat dilihat bahawa proses dari manajemen talenta sangat berkaitan satu dengan lainnya. (Berger, 2011) menyatakan bahwa manajemen talenta terdiri dari 4 proses utama yaitu :

1. Inclusion : keadaan dimana individu merasa sebagai bagian proses organisasi

2. Engagement : hubungan dimana organisasi dengan karyawan. Pada proses ini, model manajemen talenta adalah memastikan bahwa karyawan antusias dalam mengerjakan pekerjaan mereka dan mengambil langkah positif untuk meningkatkan reputasi organisasi 
3. Competencies: memastikan bahwa karyawan memiliki kompetensi yang tepat untuk bekerja dalam organisasi dan memenuhi tujuannya.

4. Retention: memastikan bahwa karyawan tetap bertahan di organisasi dan tidak pindah ke perusahaan lainnya.

Sub proses dalam manajemen talenta antara lain adalah :

1. Sourcing : proses disiplin akusisi bakat yang berfokus kepada rekrutmen dan identifikasi bakat. Berikut adalah tindakan yang dilakukan pada proses sourcing :

a. Succession Management: proses untuk mengidentifikasi dan mengembangkan orang yang memiliki potensi untuk memenuhi posisi tertentu pada sebuah organisasi

b. Branding :proses agar karyawan dalam organisasi bekerja dan memiliki perbedaan dibandingkan dengan karyawan pada organisasi lainnya.

c. Workforce Planning: proses berlanjut yang digunakan untuk menyatukan kebutuhan dan proiritas organisasi dengan kebutuhan tenaga kerjanya untuk memastikan tujuan dan persyaratan legislative, pelayanan, produksi dan peraturan dapat tercapai.

d. Recruiting :proses menentukan dan menyewa kandidiat pekerja dengan kualifikasi terbaik untuk lowongan pekerjaan dengan cara yang hemat biaya dan efektif.

2. Aligning: proses menyatukan karyawan dengan tujuan strategi perusahaan dan kebudayan perusahaan. Tindakan yang dilakukan dalam proses aligning adalah :

a. Onboarding : mekanisme yang karyawan baru dapatkan untuk memperoleh pengetahuan, kemampuan dan perilaku demi menjadi anggota organisasi yang efektif

b. Strategic Plan/Goal Aligment: penyatuan karyawan dengan tujuan serta rencana strategis organisasi

c. Performance Management: proses dimana manajer dan karyawan bekerjasama untuk merencanakan, mengawasi dan mengulas tajam karyawan dan kontribusinya terhadap perusahaan.

3. Learn and Develop: proses dimana karyawan mempelajari dan mengembangkan keahliannya demi mendapatkan karir yang lebih baik didalam organisasi.

4. Reward :hasil formulasi dan implemetasi strategi dan kebijakan yang bertujuan untuk member imbalan kepada karyawan secara adil, konsisten dan sejalan dengan niali seorang karyawan di mata organisasi.

134. Jurnal Buana Ilmu 


\section{c. Karakteristik Manajemen Talenta}

Menurut (Pella, 2011) menyebutkan bahwa keberhasilan dalam mengelola talenta karyawan berasal dari karakteristik perusahaan, antara lain :

1. Development Minset yaitu sebuah pola pikir ynag mengutamakan dalam upaya untuk mengembangkan pribadi setiap karyawan .

2. Performance Culture yaitu sitiasi dimana perusahan berusaha untuk menemukan indikator kinerja pada setiap posisi untuk dijadikan dasar dalam menilai keberhasilan seseorang dan sebagai alat ukur dalam memberikan kompensasi pada orang lain.

3. Executive Sponsorship dimana seorang General Manager(GM) secara sengaja mengabdikan waktunya untuk memberikan pembimbingan, pendidikan dan pemberdayaan kepada pegawai-pegawai yang dipersepsikan sebagai calon pemimpin masa depan.

4. Good HR Information System, dimana HRD dan pimpinan unit kerja bekerjasama dalam melakukan pemeliharaan dan pembaharuan data untuk merekam posisi pegawai berada, pernah berada pada posisi dan penugasan dimana saja serta kemana saja seharusnya pegawai dipindahkan sesuai dengan kompetensi yang dimiliki.

\section{d. Model Manajemen Talenta yang terintegrasi}

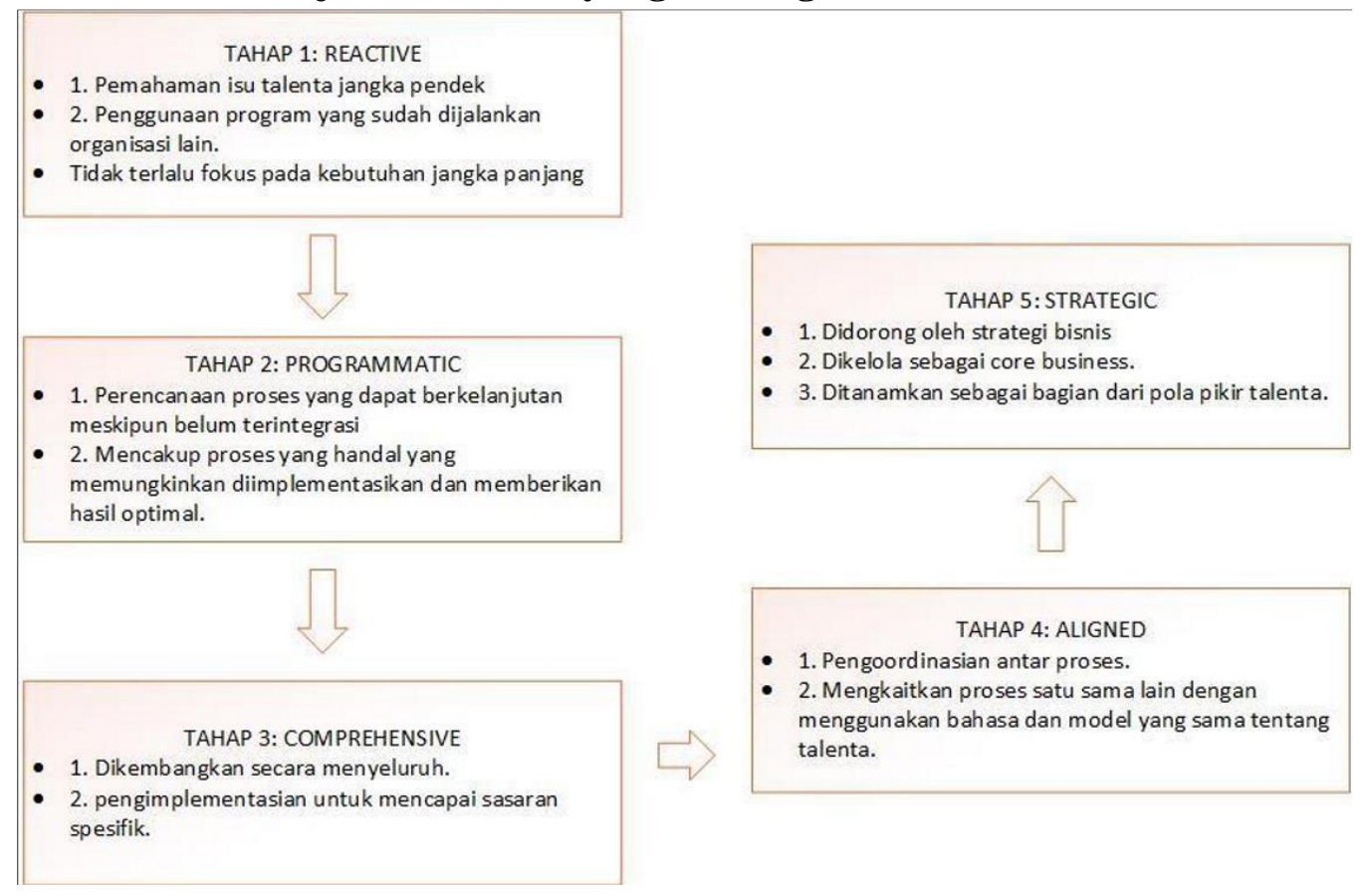

135. Jurnal Buana Ilmu 


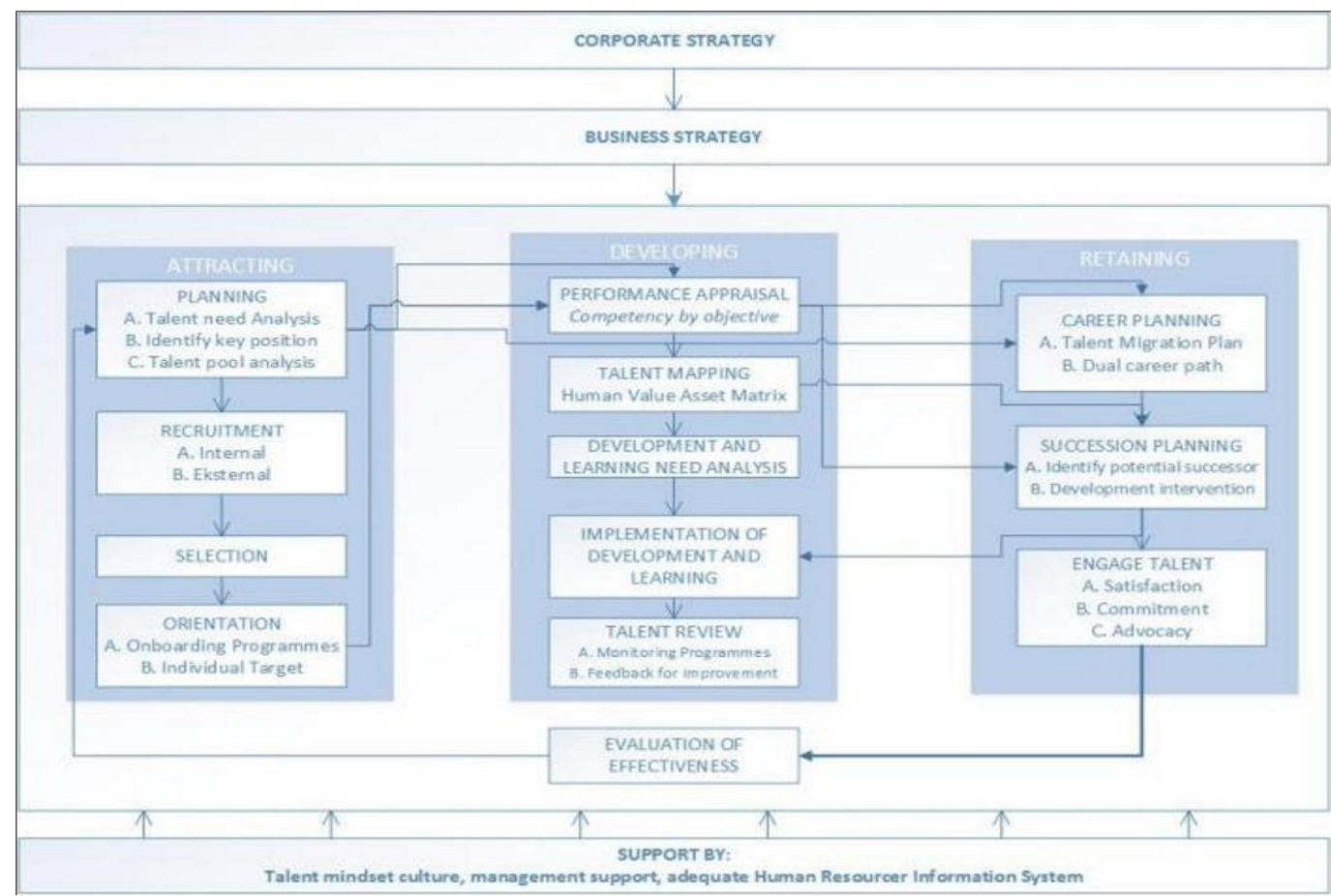

Gambar 2. Model manajemen talenta

Sumber : Talent mindset cultue, management support, adequate human resource information system

\section{e. Kinerja}

(Munandar, 2008) menyatakan bahwa penilaian kinerja adalah suatu proses penilaian dari cirri-ciri kepribadian, perilaku kerja dan hasil kerja seseorang tenaga kerja atau karyawan (pekerja atau manajer) yang dianggap menunjang dalam pekerjaannya yang digunakan sebagai bahan pertimbangan untuk mengambil keputusan tentang tindakan-tindakan terhadap bidang ketenagakerjaan.

Penilaian kinerja karyawan dimaksudkan untuk memberikan satu peluang kepada karyawan untuk rencana karir yang akan dicapai yang berasal dari kompetnesi yang dimiliki karyawan sesuai dengan kekuatan dan kelemahannya. Sedangkan menurut (Sinambela, 2012) menyatakan bahwa kinerja pegawai didefinisikan sebagai kemampuan pegaia dalam melakukan suatu keahlian tertentu. Maka dapat disimpulkan bahwa kinerja merupakan salah satu bagian penting dari sebuah perusahaan dimana maju tidaknya perusahaan tergantung pada kemampuan pegawai dalam menyelesaikan tugas tepat waktu dan sesuai dengan standar operasional yang telah ditetapkan dan diukur dengan kinerja yang telah dikeluarkan. 


\section{f. Faktor yang mempengaruhi kinerja karyawan}

(Mangkunegara, 2013) menyatakan bahwa ukuran yang perlu diperhatikan dalam penilaian kinerja adalah :

1. Kualitas kerja, yaitu kerapian, ketelitian dan keterkaitan hasil kerja dnegan mengabaikan volume pekerjaan. Kualitas kerja yang baik dapat menghidari tingkat kesalahan dalam penyelesaian suatu pekerjaan serta produktivitas kerja yang dihasilkan dapat bermanfaat bagi kemajuan perusahaan

2. Kuantitas kerja, yatiu volume kerja yang dihasilkan dibawah kondisi normal. Hal ini menunjukkan dengan banyaknya jenis pekerjaan yang dilakukan dalan satu waktu akan menghasilkan efisiensi dan efektivitas dalam mencapai tujuan perusahaan

3. Tanggung jawab, dimana menunjukkan seberapa besar karyawan dapat mempertanggungjawabkan hasil kerja, sarana dan prasarana yang dipergunakan serta perilaku kerjanya.

4. Inisiatif, yaitu menunjukkan seberapa besar kemampuan karyawan untuk menganalisis, menilai, menciptakan dan membuat keputusan terhadap penyelesaian masalah yang dihadapi.

5. Kerjasama, yaitu kesediaan karyawan untuk berpartisipasi dan bekerjasama dengan karyawan lainnya secara vertical atau horizontal didalam maupun diluar pekerjaan sehingga hasilnya semakin baik.

6. Ketaatan yaitu kesediaan karyawan dalam mematuhi peraturan-peraturan yang melakukan pekerjaan sesuai dengan instruksi yang diberikan kepada karyawan.

\section{KERANGKA BERFIKIR}

\section{Tabel 1. Penelitian Terdahulu}

\section{Nama Peneliti}

Nisa, 2016. Pengaruh Manajemen Talenta dan Manajemen Pengetahuan Terhadap Kinerja Karyawan ( Studi pada Karyawan PT.PLN Persero Distribusi Jawa timur, Surabaya)

\section{Hasil Penelitian}

Penerapan manajemen talenta dan manajemen pengetahuan pada PT.PLN (Persero) Distribusi Jawa Timur, Surabaya telah berjalan dimana variabel manajemen talenta dan manajemen pengetahuan berpengaruh positif dan signifikan. Namun ada beberapa hambatan yang terjadi dimana dalam pelaksanaan pada manajemen pengetahuan tim KM kesulitan untuk berkumpul dan membahas rencana kedepannya, selain itu karyaawan sering merasa 
bahwa ilmunya tidak cukup istimewa untuk disebarkan serta ada karyawan yang tidak ingin membagi ilmu kepada karyawan lain karena takut tersaingi. Hal ini diharapkan perusahaan dapat terus meningkatkan efektifitas penerapan manajemen talenta yang berkaitan dengan knowledge sharing.

Kusumowardani, 2016. Analisis pengaruh manajemen talenta dan global Minset terhadap kinerja dengan komitmen dan Iturnover intention variabel intervening (Studi Pada Karyawan PT.Cipta Busana Mandiri depok)
Hasil penelitian menunjukan bahwa:

1. Manajemen bakat memiliki dampak positif dan signifikan terhadap komitmen organisasi

2. Pola pikir global memiliki signifikan terhadap komitmen organisasi

3. Manajemen bakat berpengaruh secara negative terhadap niat turn over

4. Pola pikir global berpengaruh negative terhadap kinerja karyawan

5. Komitmen organisasi berpengaruh negative dan signifikan terhadap intense turnover

6. Komitmen organisasi berpengaruh positif dan signifikan terhadap kinerja karyawan

Anugrahini Irawati, Bambang Sudarsono, Lala Lestari(2017) Pengaruh Manajemen Bakat Dan Pengelolaan Sumber Daya Manusia Terhadap Kinerja Karyawan Pt Jawa Pos Media Televisi (Jtv) Di Surabaya manajemen bakat berpengaruh positif dan signifikan terhadap kinerja karyawan; (2) variabel pengelolaan sumber daya manusia berpengaruh positif dan signifikan terhadap kinerja karyawan; (3) variabel manajemen bakat dan pengelolaan SDM berpengaruh positif dan signifikan secara bersamasama atau simultan terhadap kinerja karyawan sebesar 67,6\%; (4) variabel pengelolaan SDM berpengaruh dominan terhadap kinerja karyawan.

Sumber: data Sekunder 2019

Bedasarkan penelitian terdahulu, ingin membuktikan bagaimana pengaruh manajemen talenta terhadap kinerja pegawai UBP Karawang pada saat ini.

\section{HIPOTESIS}

Berdasarkan data diatas maka hipotesis yang didapat adalah :

$\mathrm{Ha}$ : ada pengaruh antara manajemen talenta dengan kinerja karyawan

Ho: tidak ada pengaruh antara manajemen talenta dengan kinerja karyawan 


\section{METODE PENELITIAN}

\section{a. Desain Penelitian}

Penelitian ini menggunakan metode kuantitatif dengan menggunakan metode statistik dengan membuktikan bagaimana pengaruh manajemen talenta terhadap kinerja pegawai UBP Karawang.

\section{b. Variabel Penelitian}

Penjelasan penelitian ini perlu diuraikan variabel yang diteliti meliputi:

Tabel 2. Operasionalisasi Variabel

\begin{tabular}{|c|c|c|}
\hline Variabel & Dimensi & Indikator \\
\hline Manajemen Talenta & $\begin{array}{l}\text { 1. Sourcing } \\
\text { 2. Aligning } \\
\text { 3. Learn and Develop } \\
\text { 4. Reward }\end{array}$ & $\begin{array}{l}\text { 1.a. Identifikasi potensi kemampuan } \\
\text { 1.b. Menentukan kandidat pegawai sesuai kualifikasi } \\
\text { 2.a. Memberikan diklat kepada pegawai baru sehingga efektif } \\
\text { 2.b. Kerjasama pimpinan dengan pegawai mencapai tujuan } \\
\text { 3.a. Perencanan karir pegawai } \\
\text { 3.a Pengembangan keahlian dengan diklat terencana. } \\
\text { 4.a. Kebijakan tentang reward secara adil dan konsiten. }\end{array}$ \\
\hline Kinerja Pegawai & $\begin{array}{ll}\text { 1. } & \text { Kualitas kerja } \\
\text { 2. } & \text { Kuantitas kerja } \\
\text { 3. } & \text { Tanggung jawab } \\
\text { 4. } & \text { Inisiatif } \\
\text { 5. } & \text { Kerjasama } \\
\text { 6. } & \text { Ketaatan }\end{array}$ & $\begin{array}{l}\text { 1.a. Kualitas hasil pekerjaan } \\
\text { 2.a. Produktifitas kerja yang efektif } \\
\text { 3.a. pertanggungjawaban beban kerja dan penyelesaiana } \\
\text { pekerjaan } \\
\text { 4.a. Penyelesaian masalah dengan analisis, sehingga menjadi } \\
\text { keputusan yang tepat } \\
\text { 5.a. Partisipasi dan kerjasama pegawai dalam kegiatan } \\
\text { 6.a. Kepatuhan dengan peraturan yang ditetapkan. }\end{array}$ \\
\hline
\end{tabular}

Sumber: data primer 2019

\section{c. Model Penelitian}

Model penelitian ini menggunakan regresi linier sederhana yaitu sebagai berikut

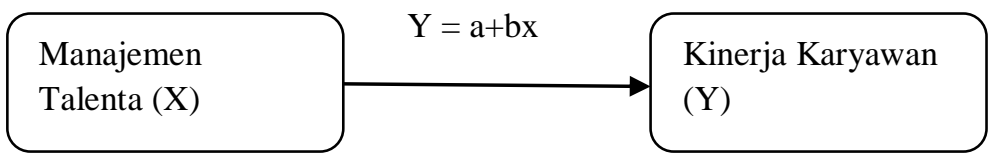

Gambar 3. Model Penelitian 


\section{d. Teknik Pengumpulan Data}

Populasi penelitian adalah seluruh pegawai UBP Karawang baik Tendik (tenaga kependidikan) maupun Dosen berjumlah 170 orang. Sedangkan sampelnya yang didapat melalui Teknik simple random sampling slovin dengan tingkat kesalahan 10\% yaitu berjumlah 63 orang sebagai sampel.

Data yang digunakan dalam penelitian ini adalah data primer dan data sekunder. Data primer diperoleh dari wawancara yang dilakukan dengan pihak stakeholder UBP Karawang atau Divisi HRIS (HR Management System) dan dari hasil kuisioner yang diberikan kepada karyawan UBP Karawang. Data sekunder diperoleh peneliti dengan mencari dan melakukan studi pustaka mengenai manajemen talenta dan kinerka karyawan berdasarkan buku, jurnal, artikel, website dan peneliti terdahulu.

\section{e. Teknik Analisis Data}

Penelitian ini dilakukan penulis dengan tujuan untuk mengetahui Pengaruh Manajemen Talenta Terhadap Kinerja Karyawan UBP Karawang. Tahapan dalam penelitian ini adalah sebagai berikut :

1. Uji keabsahan data
a. Validitas $r$ hitung $>0,3$ (Instrument Valid)
b. Reliabilitas Croanbach's Alpha >0,6. (Instrumen Reliabel)

2. Uji Prasyarat

3. Uji normalitas menggunakan uji kolmogorov-smirnov dengan menggunakan SPSS. Uji Normalitas Sig. Hitung >0,05 berdistribusi normal.

4. Uji Regersi linier sederhana

5. Uji Signifikasi (uji t)

6. Uji Determinasi (uji $\mathrm{R}^{2}$ )

\section{HASIL PENELITIAN}

\section{a. Analisis Data}

Analisis data yang disajikan adalah hasil dari pengolahan data primer dari tabulasi data kuesioner yang dianalisis mengunakan sofwere spss. Berdasarkan hasil dari analisis data didapatkan beberapa uji validitas, reabilitas dan noermalitas sebagai berikut: 


\section{Uji Validitas}

Tabel 3 Uji Validitas

\begin{tabular}{|c|c|c|c|c|c|c|c|c|c|c|c|c|c|c|c|}
\hline \multirow{2}{*}{ No res } & \multicolumn{8}{|c|}{ Variabel Manajemen Talenta } & \multicolumn{7}{|c|}{ Variabel Kinerja Pegawai } \\
\hline & $\mathrm{X} 1$ & $\mathrm{X} 2$ & $\mathrm{X} 3$ & $\mathrm{X} 4$ & $\mathrm{X} 5$ & X6 & $\mathrm{X7}$ & Jml & Y1 & Y2 & Y3 & Y4 & Y5 & Y6 & $\mathrm{Jml}$ \\
\hline 1 & 2 & 3 & 1 & 3 & 3 & 4 & 3 & 19 & 2 & 3 & 3 & 3 & 3 & 3 & 17 \\
\hline 2 & 3 & 3 & 3 & 4 & 3 & 3 & 2 & 21 & 3 & 3 & 3 & 3 & 3 & 1 & 16 \\
\hline 3 & 4 & 2 & 3 & 3 & 3 & 2 & 4 & 21 & 4 & 4 & 4 & 4 & 2 & 5 & 23 \\
\hline 4 & 2 & 3 & 3 & 1 & 3 & 3 & 3 & 18 & 3 & 3 & 4 & 4 & 4 & 3 & 21 \\
\hline 5 & 3 & 2 & 3 & 4 & 2 & 3 & 3 & 20 & 4 & 4 & 2 & 3 & 3 & 4 & 20 \\
\hline 6 & 3 & 3 & 2 & 2 & 4 & 3 & 2 & 19 & 5 & 4 & 4 & 4 & 2 & 2 & 21 \\
\hline 7 & 2 & 4 & 2 & 3 & 4 & 4 & 5 & 24 & 5 & 5 & 3 & 3 & 2 & 3 & 21 \\
\hline 8 & 3 & 3 & 2 & 3 & 5 & 4 & 3 & 23 & 4 & 3 & 3 & 3 & 4 & 4 & 21 \\
\hline 9 & 3 & 4 & 3 & 3 & 3 & 3 & 3 & 22 & 4 & 3 & 4 & 4 & 1 & 4 & 20 \\
\hline 10 & 4 & 3 & 4 & 4 & 4 & 4 & 2 & 25 & 4 & 4 & 3 & 3 & 3 & 3 & 20 \\
\hline 11 & 1 & 2 & 2 & 3 & 3 & 3 & 3 & 17 & 3 & 2 & 4 & 2 & 4 & 3 & 18 \\
\hline 12 & 4 & 4 & 4 & 2 & 4 & 5 & 4 & 27 & 4 & 4 & 5 & 5 & 5 & 5 & 28 \\
\hline 13 & 3 & 4 & 3 & 5 & 2 & 2 & 3 & 22 & 3 & 5 & 4 & 4 & 4 & 4 & 24 \\
\hline 14 & 4 & 4 & 4 & 5 & 4 & 4 & 4 & 29 & 4 & 4 & 4 & 4 & 4 & 4 & 24 \\
\hline 15 & 5 & 4 & 5 & 3 & 4 & 3 & 4 & 28 & 4 & 3 & 5 & 5 & 4 & 4 & 25 \\
\hline 16 & 2 & 3 & 5 & 4 & 1 & 2 & 1 & 18 & 5 & 2 & 4 & 3 & 3 & 4 & 21 \\
\hline 17 & 3 & 2 & 4 & 3 & 2 & 1 & 2 & 17 & 4 & 3 & 3 & 3 & 3 & 3 & 19 \\
\hline 18 & 3 & 3 & 4 & 2 & 3 & 2 & 3 & 20 & 3 & 2 & 3 & 3 & 3 & 3 & 17 \\
\hline 19 & 4 & 3 & 3 & 2 & 1 & 3 & 2 & 18 & 3 & 3 & 5 & 4 & 4 & 3 & 22 \\
\hline 20 & 2 & 2 & 3 & 3 & 2 & 2 & 2 & 16 & 3 & 3 & 3 & 3 & 3 & 3 & 18 \\
\hline $\mathrm{r}$ & 0,67 & 0,73 & 0,34 & 0,32 & 0,66 & 0,61 & 0,62 & 424 & 0,39 & 0,49 & 0,69 & 0,81 & 0,42 & 0,71 & 416 \\
\hline Status & Valid & Valid & Valid & Valid & Valid & Valid & Valid & & Valid & Valid & Valid & Valid & Valid & Valid & \\
\hline
\end{tabular}

Sumber: olah data 2019

Berdasarkan tabel 3 tentang uji validitas dengan menggunakan product moment pearson hasil olah data diperoleh bahwa semua indikator instrumen penelitian dinyatakan valid karena $r>0,3$. Maka intrumen penelitian tersebut dapat dilanjutkan ke tahap uji reabilitas.

\section{Uji Reabilitas}

Tabel 4 Uji Reabilitas

Reliability Statistics

\begin{tabular}{c|r|r|r}
\hline \multicolumn{2}{c|}{ Variabel Manajemen Talenta } & \multicolumn{2}{c}{ Variabel Kinerja Pegawai } \\
\hline Cronbach's Alpha & N of Item & Cronbach's Alpha & N of Items \\
\hline 0,623901903 & 7 & 0,60212766 & 6 \\
\hline
\end{tabular}

Sumber: olah data 2019

Variabel manajemen talenta diperoleha nilai Cronbach's Alpha sebesar 0,623 dan variabel kinerja pegawai diperoleh nilai Cronbach's Alpha sebesar 0,602. Maka kedua variabel tersebut dinyatakan realibel karena Cronbach's Alpha $>0,6$. 


\section{Uji Normalitas}

Pengujian normalitas pada penelitian ini menggunakan kolmogorov spirnov dengan signifikasi 0,05, maka didapat hasil spss sebagai berikut:

Tabel 5 Uji normalitas

\begin{tabular}{l|l|r}
\hline \multicolumn{2}{l}{ One-Sample Kolmogorov-Smirnov Test } \\
\hline $\mathrm{N}$ & & $\begin{array}{c}\text { Unstandardized } \\
\text { Residual }\end{array}$ \\
\hline Normal Parametersa & Mean & 63 \\
\hline & Std. Deviation & 2,464269236 \\
\hline Most Extreme Differences & Absolute & 0,060 \\
\hline & Positive & 0,060 \\
\hline Kolmogorov-Smirnov Z & Negative & $-0,047$ \\
\hline Asymp. Sig. (2-tailed) & & 0,473 \\
\hline
\end{tabular}

a. Test distribution is Normal.

Sumber: olah data 2019

Berdasarkan hasil uji normalitas didapat sig hitung 0,978 > sig kritis 0,05. Maka dapat dikatakan variabel tersebut berdistribusi normal. Hasil pengujian tersebut dapat dilanjutkan ke analisis regresi linier sederhana.

\section{b. Analisis Regresi Linier Sederhana}

Analisis regresi sederhana diperlukan menghitung koefisien regresi tersebut. Berdasarkan hasil perhitungan spss. Maka didapatkan koefisien regresi sebagai berikut:

Tabel 6 Koefisien Regresi Sederhana

\begin{tabular}{l|c|c|c|c|c|c}
\hline \multicolumn{2}{c|}{} & \multicolumn{2}{c|}{$\begin{array}{c}\text { Unstandardized } \\
\text { Coefficients }\end{array}$} & $\begin{array}{c}\text { Standardized } \\
\text { Coefficients }\end{array}$ & & \multirow{2}{*}{ Sig. } \\
\cline { 3 - 7 } Model & B & Std. Error & Beta & t & Sicficientsa \\
\hline 1 & (Constant) & 8,99651 & 1,971302631 & & 4,563738 & $.000^{a}$ \\
\hline & $\begin{array}{c}\text { Manajemen } \\
\text { Talenta }\end{array}$ & 0,591623 & 0,097083583 & 0,61515485 & 6,093955 & $.000^{\mathrm{a}}$ \\
\hline
\end{tabular}

a. Dependent Variable: Kinerja Pegawai

Sumber: olah data 2019

Berdasarkan perhitungan koefisien regresi didapat konstanta sebesar 8,997 sedangkan koefisien b sebesar 0,592. Yang berarti setiap ada kenaikan 1 variabel manajemen talenta maka 
akan terjadi kenaikan 0,592 ditambah konstanta 8,996. Sehingga didapatkan sebuah rumus regresi yaitu

$\hat{y}=8,997+0,592 x$

\section{c. Analisis Signifikansi (uji t)}

Berdasarkan tabel 6 diperoleh t hitung adalah 6,09. Sedangkan t tabel adalah 1,99 diperoleh dari derajat kebebasan $=63-2=61$. Maka untuk uji signifikansi t hitung $>t$ tabel $(6,09>1,99)$ dapat dikatakan pengaruh manajemen talenta terhadap kinerja pegawai signifikan.

\section{d. Analisis Determinasi (uji $\mathbf{R}^{2}$ )}

Uji determinasi diperoleh dari hasil R square dari pengolahan spss. Berikut hasil perhitungannya:

Tabel 7 Uji determinasi

\begin{tabular}{l|c|c|c|c}
\hline \multicolumn{5}{|c}{ Model Summaryb } \\
\hline Model & $\mathrm{R}$ & R Square & $\begin{array}{l}\text { Adjusted R } \\
\text { Square }\end{array}$ & $\begin{array}{l}\text { Std. Error of } \\
\text { the Estimate }\end{array}$ \\
\hline 1 & 0,61515485 & 0,378415489 & 0,36822558 & 2,484386053 \\
\hline
\end{tabular}

a. Predictors: (Constant), Manajemen Talenta

b. Dependent Variable: Kinerja

Diketahui berdasarkan hasil tabel 7 diperoleh R Square adalah 0,378. Atau pengaruh manajemen talenta terhadap kinerja pegawai sebesar $37,8 \%$, sedangkan sisanya dari pengaruh lain sebesar $62,2 \%$.

\section{KESIMPULAN}

Hasil dari analisis dan pembahasan sebelumnya maka dapat disimpulkan bahwa terdapat pengaruh signifikan manajemen talenta terhadap kinerja pegawai sebesar $37,8 \%$.

\section{DAFTAR PUSTAKA}

Berger, L. .. (2011). The Talent Management Handbook: Creating Organizational Excellence by Identifying, Developing, and Promoting the Best People. . 2nd: New York: McGraw-Hill Companies.

Boudreau, J. \&. (2005). Talentship and the new paradigma for human resource management: from profesional practices to strategic talent decision science. Pelope and Strategic , 17.

Bratton, J. \&. (2012). Human resource management: theory and practice. Palgrave Macmillan. Human Resource Management review , 43-56.

Darmin, A. A. (2011). Talent Management Mengembangkan SDM Untuk Mencapai Pertumbuhan dan Kinerja Prima. Jakarta: Gramedia Pustaka Utama.

Farndale, E. S. (2010). The role of the corporate HR function in global talent management. . Journal of world business , 161-168.

Irawati, Anugrahini dkk. 2017. Pengaruh Manajemen Bakat Dan Pengelolaan Sumber Daya Manusia Terhadap Kinerja Karyawan PT Jawa Pos Media Televisi (JTV) Di Surabaya. Journal Trounojoyo vol 3 No 1

143. Jurnal Buana Ilmu 
Isanawikrama, F. A. (2017). Analisis Pengaruh Talent Management Terhadap Organizational Performance Dan Dampaknya Pada Employee Retention. Jurnal Administrasi dan Kesekretarisan , 150-161.

Iwan Sukoco \& Ashar R. F. (2016). THE ANALYSIS OF TALENT MANAGEMENT STRATEGY USING ORGANIZATIONAL COMPETENCY APPROACH IN PT PINDAD (PERSERO) BANDUNG CITY. Jurnal AdBispreneur Vol.1 No. 1 , 85-102.

Kusumowardani, A. \&. (2016). Analisis pengaruh manajemen talenta dan global Minset terhadap kinerja dengan komitmen dan Iturnover intention variabel intervening (Studi Pada Karyawan PT.Cipta Busana Mandiri depok). Diponegoro Journal of Management Volume 5, Nomor 3, 1-15.

Lewis, R. d. (2006). Talent Management : A Critical Review. Human Resource Management Review .

Lockwood, N. (2005). Talent Management overview: Talent Management Series Part I. . Society for Human Resource Management .

Mangkunegara, A. P. (2013). Manajemen Sumber Daya Manusia Perusahaan. Bandung: Remaja Rosdakarya.

Mellahi, C. \&. (2009). Strategic talent management: A Review and reseach agenda. Human Resource Management Review , 304-313.

Munandar, A. S. (2008). Psikologi Industri dan organisasi. Universitas Indonesia (UI- Press).

Nisa, R. C. (2016). Pengaruh Manajemen Talenta dan Manajemen Pengetahuan Terhadap Kinerja Karyawan ( Studi pada Karyawan PT.PLN Persero Distribusi Jawa timur, Surabaya). Jurnal Administrasi Bisnis (JAB)|Vol. 39 No.2 .

Pella, D. A. (2011). Talent Management (Mengembangkan SDM untuk Mencapai Pertumbuhan dan Kinerja Prima). Jakatra: PT.Gramedia Pustaka Utama.

Ramlall, S. (2003). Organizational application managing employee retention as a strategyfor increasing organizational competitiveness. . Applied HRM Research, 8(2) , 63-72.

Sinambela, L. P. (2012). Kinerja Pegawai Teori Pengukuran dan Implikasi. Yogyakarta: Graha Ilmu.

Smilansky, J. (2008). Developing Executive Talent: Best practice from Global Leader. John Wiley \& Sons.

Wright, P. \&. (2011). Exploring human capital: putting 'human'back into strategic human resource management. . Human Resource Management Journal , 93-104.

Yamall, J. (2011). Maximising the effectiviness of talent pools:a review of case study literatur. Leadership \& Organization Development Journal, 32 (2) , 510-526. 